\title{
Pengaruh Suhu Dan Konsentrasi Larutan Gula Terhadap Proses Dehidrasi Osmosis Pepaya (Carica papaya L.)
}

\section{(Effect of Temperature and Concentration of Sugar Solution in The Process of Osmotic Dehydration of Papaya (Carica papaya L.))}

\author{
Liem Aras ${ }^{* 1)}$, Supratomo ${ }^{2)}$ dan Salengke ${ }^{3)}$ \\ ${ }^{1)}$ Program Studi Keteknikan Pertanian Universitas Hasanuddin \\ 2) Program Studi Keteknikan Pertanian Universitas Hasanuddin \\ 3) Program Studi Keteknikan Pertanian Universitas Hasanuddin \\ *email : liemaaras@gmail.com
}

\begin{abstract}
ABSTRAK
Buah pepaya (Carica papaya L.) tergolong buah yang populer dan digemari oleh hampir seluruh masyarakat di dunia. Pepaya banyak dibudidayakan oleh masyarakat baik sebagai hobi ataupun usaha komersil. Hal ini karena pepaya memiliki banyak kelebihan. Buah pepaya menjadi salah satu komoditi yang sangat mudah rusak, hal tersebut terjadi akibat beberapa faktor, seperti: aktivitas dan pertumbuhan mikroba pada buah pepaya, aktivitas enzim-enzim di dalam buah pepaya, perlakuan suhu, serta beberapa faktor lainnya yang dapat merusak buah pepaya. Dehidrasi osmosis merupakan teknik pengurangan kadar air yang dapat digunakan untuk mengatasi permasalahan tersebut yaitu dengan cara perendaman bahan pada larutan berkonsentrasi tinggi. Penelitian ini dilaksanakan pada bulan September 2018 hingga bulan Oktober 2018 di Laboratorium Pengolahan Pangan dan Analisis Kimia Universitas Hasanuddin. Tujuan dari penelitian ini yaitu untuk mengetahui pengaruh suhu dan konsentrasi larutan gula terhadap kadar air akhir, penurunan bobot (WR), jumlah padatan yang masuk (SG) dan jumlah air yang keluar dari bahan (WL) pada pepaya selama proses dehidrasi osmosis dan mengetahui suhu dan konsentrasi yang optimal dalam proses dehidrasi pepaya. Metode yang digunakan pada penelitian ini adalah dengan menggunakan rancangan acak lengkap yang disusun secara faktorial dengan 2 faktor dan masing-masing faktor terdiri atas 3 level yaitu kadar gula $40^{\circ}$ Brix, $50^{\circ}$ Brix, $60^{\circ}$ Brix dan suhu perendaman $40^{\circ} \mathrm{C}, 50^{\circ} \mathrm{C}, 60^{\circ} \mathrm{C}$ dengan 3 kali ulangan. Berdasarkan hasil penelitian diperoleh bahwa perlakuan suhu $60^{\circ} \mathrm{C}$ dan konsentrasi larutan $60^{\circ}$ Brix menghasilkan kadar air yang paling rendah, dan sama halnya seperti peningkatan nilai Solid Gain (SG) paling tinggi juga terjadi pada suhu $60^{\circ} \mathrm{C}$ dan konsentrasi $60^{\circ}$ Brix. Perlakuan suhu perendaman $50^{\circ} \mathrm{C}$ dan konsentrasi larutan gula $50^{\circ}$ Brix menghasilkan Weight Reduction (WR) yang paling tinggi, sedangkan nilai Water Loss (WL) yang paling tinggi juga berada pada kombinasi perlakuan suhu perendaman $50^{\circ} \mathrm{C}$ dan konsentrasi larutan gula $50^{\circ} \mathrm{Brix}$.
\end{abstract}

Kata Kunci: Dehidrasi Osmosis, Suhu, Konsentrasi Larutan, Pepaya

\section{PENDAHULUAN}

Buah pepaya (Carica papaya L.) tergolong buah yang populer dan digemari oleh hampir seluruh masyarakat di dunia.
Pepaya banyak dibudidayakan oleh masyarakat, baik sebagai hobi ataupun usaha komersil. Hal ini karena pepaya memiliki banyak kelebihan dan manfaat, diantaranya: (1) dapat dibudidayakan di pekarangan atau 
kebun (2) cepat berbuah (3) memiliki buah yang lebat (4) rasanya cukup manis (5) tumbuh tanpa perawatan yang rumit (6) memiliki kandungan gizi yang cukup banyak.

Dehidrasi osmosis menjadi salah satu metode untuk mengurangi kadar air dalam bahan pangan. Dengan cara perendaman pada larutan berkonsentrasi tinggi. Dengan metode dehidrasi osmosis, bahan pangan yang direndam akan mengalami penurunan bobot. Hal tersebut dapat terjadi karena cairan yang terdapat di dalam bahan pangan keluar dan zat terlarut (solute) dari larutan masuk ke dalam bahan pangan. Bahan pangan yang dihasilkan dari proses ini memiliki kelebihan dibandingkan metode pengawetan bahan pangan lainnya yakni, antara lain: (1) Meningkatkan kualitas produk bahan makanan yang diawetkan, (2) Memberikan kisaran kadar air dan zat terlarut bahan yang diinginkan untuk pengolahan pangan (3) Meminimalisasi stress karena panas dan (4) Mengurangi input energi pada pengeringan konvensional (Witono et al., 2013).

Berdasarkan pemaparan di atas, maka perlu dilakukan penelitian tentang pengaruh suhu dan konsentrasi larutan gula terhadap proses dehidrasi osmosis buah pepaya mengkal (Carica papaya L.) untuk mempelajari dan mengetahui proses dehidrasi osmosis pada buah pepaya mengkal, dengan mengukur parameter pengukuran selama proses berlangsung.

\section{METODOLOGI PENELITIAN}

\section{Waktu dan Tempat Penelitian}

Penelitian ini dilaksanakan pada bulan September 2018 hingga bulan Oktober 2018 di Laboratorium Pengolahan Pangan dan Analisis Kimia Universitas Hasanuddin.

\section{Alat}

Alat yang digunakan pada penelitian ini adalah water bath, oven, wadah ukuran $2 \ell$, sendok, cawan, timbangan analitik, toples, termometer, jangka sorong, pisau dan talenan.

\section{Bahan}

Bahan yang digunakan pada penelitian ini adalah pepaya california mengkal (Carica papaya L.), gula kristal $5 \mathrm{~kg}$, aquades, plastik, tissue roll, kertas label dan aluminium foil.

\section{Prosedur Penelitian}

Rancangan penelitian yang digunakan adalah Rancangan Acak Lengkap Faktorial yang terdiri atas 2 faktor. Masing-masing faktor terdiri atas 3 level dengan 3 kali ulangan. Faktor tersebut adalah:

Faktor I: Konsentrasi Gula

$\mathrm{K} 1=40^{\circ}$ Brix

$\mathrm{K} 2=50^{\circ}$ Brix

$\mathrm{K} 3=60^{\circ}$ Brix

Faktor II: Suhu Perendaman

$\mathrm{T} 1=40^{\circ} \mathrm{C}$

$\mathrm{T} 2=50^{\circ} \mathrm{C}$

$\mathrm{T} 3=60^{\circ} \mathrm{C}$

\section{Penyiapan Larutan Osmosis}

Adapun tahap-tahap dalam menyiapkan larutan osmosis yakni, sebagai berikut (Herdiyantoro, 2013):

1. Menyiapkan alat dan Bahan

2. Menimbang gula sebanyak $800 \mathrm{~g}, 1000 \mathrm{~g}$ dan $1200 \mathrm{~g}$ dengan menambahkan air sebanyak $1200 \mathrm{ml}, 1000 \mathrm{ml}$ dan $800 \mathrm{ml}$.

3. Memasukkan gula dan air ke dalam panci.

4. Memasak larutan gula, dilakukan proses pengadukan hingga padatan gula terlarut seluruhnya.

5. Memastikan konsentrasi pada larutan telah sesuai, dengan menggunakan refraktometer.

6. Memasukkan hasil larutan ke dalam wadah untuk dilakukan pendinginan selama 1 jam atau lebih pada suhu ruang.

\section{Penyiapan Sampel}

Adapun tahap-tahap dalam menyiapkan sampel yakni, sebagai berikut (Kartika dan Fithri, 2015):

1. Menyiapkan alat dan bahan.

2. Mengupas bagian kulit pepaya dan memotong pepaya dengan setiap sampel berbentuk kubus dengan ukuran $2 \mathrm{~cm} x$ $2 \mathrm{~cm} \times 2 \mathrm{~cm}$.

3. Memberi tanda pada masing-masing sampel.

4. Memasukkan setiap potongan sampel ke dalam wadah. 


\section{Proses dehidrasi osmosis}

Adapun tahap-tahap dalam perendaman sampel dengan larutan gula yakni, sebagai berikut (Sharma et al., 2000):

1. Menyiapkan alat dan bahan

2. Memasukkan gelas breaker yang berisi larutan dan sampel ke dalam sebuah water bath, yang dipertahanakan pada suhu $40^{\circ} \mathrm{C}$.

3. Memasukkan 5 potongan sampel ke dalam masing-masing 3 toples, yang sebelumnya telah diberi tanda dengan spidol untuk membedakan perubahan pada setiap sampel.

4. Menutup setiap toples, untuk mencegah air masuk ke dalam toples selama proses berlangsung

5. Mengambil setiap sampel setelah 1 jam perendaman dan menghilangkan sisa gula dari sampel dengan kuas dan sisa larutan dengan menggunakan tissue.

6. Mengukur dimensi sampel dengan menggunakan jangka sorong dan menimbang berat sampel setelah perendaman setiap 1 jam sampai 5 jam.

7. Mencatat hasil pengukuran yang telah diperoleh selama perendaman setiap 1 jam sampai 5 jam.

8. Mengulangi prosedur 1 sampai 7 dengan suhu $50^{\circ} \mathrm{C}$ dan $60^{\circ} \mathrm{C}$.

\section{Parameter Penelitian}

\section{Kadar air Akhir}

Pengukuran kadar air dilakukan dengan metode gravimetrik/oven yaitu dilakukan dengan memasukkan sampel sebelum perendaman kedalam cawan yang telah ditimbang untuk mendapatkan data berat awal $\left(\mathrm{W}_{0 \mathrm{x}}\right)$. Setelah itu, dimasukkan dalam oven hingga bobot konstan selama 24 jam pada suhu $105^{\circ} \mathrm{C}$. Lalu, bahan dikeluarkan dan dimasukkan kedalam desikator selama 15 menit $\left(\mathrm{W}_{\mathrm{x}}\right)$. Data yang diperoleh, kemudian diolah dengan rumus dibawah:

$$
\mathrm{Mx}=\frac{\mathrm{W} 0 \mathrm{x}-\mathrm{Sx}}{\mathrm{w} 0 \mathrm{x}} \times 100 \%
$$

Keterangan:

Mx : Kadar air basis basah pada sampel $\mathrm{x}$ $(\%)$.

$\mathrm{W}_{0 \mathrm{x}}$ : Berat sampel $\mathrm{x}$ awal pepaya pada waktu $\mathrm{t}=0(\mathrm{~g})$.
Jurnal AgriTechno. Vol. 12 (2): 110-120

https://doi.org/10.20956/at.v0i0.219

$\mathrm{S}_{\mathrm{x}} \quad$ : Berat sampel $\mathrm{x}$ kering pada waktu $\mathrm{t}$ (g).

\section{Penurunan Bobot (WR)}

Mengambil sampel data awal sebelum perendaman $\left(\mathrm{W}_{0 \mathrm{x}}\right)$ dan data berat sampel kering sebelum perendaman $\left(\mathrm{S}_{0 \mathrm{x}}\right)$. Kemudian sampel yang telah direndam, diambil dan ditiriskan. Kemudian, diletakkan pada cawan dan ditimbang $\left(\mathrm{W}_{\mathrm{x}}\right)$.

keterangan:

$$
\mathrm{WRx}=\frac{\mathrm{W} 0 \mathrm{x}-\mathrm{Wx}}{\mathrm{s} 0 \mathrm{x}}
$$

WRx : Penurunan bobot sampel x (g).

$\mathrm{W}_{0 \mathrm{x}} \quad$ : Berat sampel $\mathrm{x}$ pada waktu $\mathrm{t}=0$

(g).

$\mathrm{W}_{\mathrm{x}} \quad$ : Berat sampel $\mathrm{x}$ setelah perendaman pada waktu $\mathrm{t}(\mathrm{g})$.

$\mathrm{S}_{0 \mathrm{x}} \quad$ : Berat kering sampel $\mathrm{x}$ sebelum perendaman $(\mathrm{g})$.

\section{Padatan terlarut yang masuk dalam bahan (SG)}

Menimbang sampel kering sebelum perendaman $\left(\mathrm{S}_{0 \mathrm{x}}\right)$, dan sampel yang telah direndam pada waktu $t$, dikeringkan hingga bobot konstan selama 24 jam pada suhu $105^{\circ} \mathrm{C} \quad\left(\mathrm{S}_{\mathrm{x}}\right)$. Data yang telah diperoleh kemudian dilakukan perhitungan sebagai berikut:

$$
\mathrm{SGx}=\frac{\mathrm{Sx}-\mathrm{S0x}}{\mathrm{S} 0 \mathrm{x}}
$$

keterangan:

SGx : Solid gain waktu t (g).

$\mathrm{S}_{0 \mathrm{x}}$ :Berat kering sampel $\mathrm{x}$ sebelum perendaman $(\mathrm{g})$.

$\mathrm{S}_{\mathrm{x}}$ :Berat kering sampel $\mathrm{x}$ setelah perendaman pada waktu $\mathrm{t}(\mathrm{g})$.

Jumlah air yang keluar dari bahan (WL)

Jumlah air yang keluar dari bahan dapat dihitung menggunakan data-data yang telah diolah yakni jumlah air yang keluar dari bahan $\left(\mathrm{WR}_{\mathrm{x}}\right)$ dan padatan terlarut yang masuk dalam bahan $\left(\mathrm{SG}_{\mathrm{x}}\right)$. kemudian dianalisis dengan perhitungan sebagai berikut:

$$
\mathrm{WL}_{\mathrm{x}}=\mathrm{WR}_{\mathrm{x}}+\mathrm{SG}_{\mathrm{x}}
$$

Keterangan:

$\mathrm{WL}_{\mathrm{x}}$ : Jumlah air yang keluar dari bahan pada sampel $\mathrm{x}(\mathrm{g})$.

$\mathrm{WR}_{\mathrm{x}}$ : Penurunan bobot pada sampel $\mathrm{x}(\mathrm{g})$.

$\mathrm{SG}_{\mathrm{x}}$ : Padatan terlarut yang masuk dalam bahan pada sampel x (g). 


\section{Bagan Alir Penelitian}

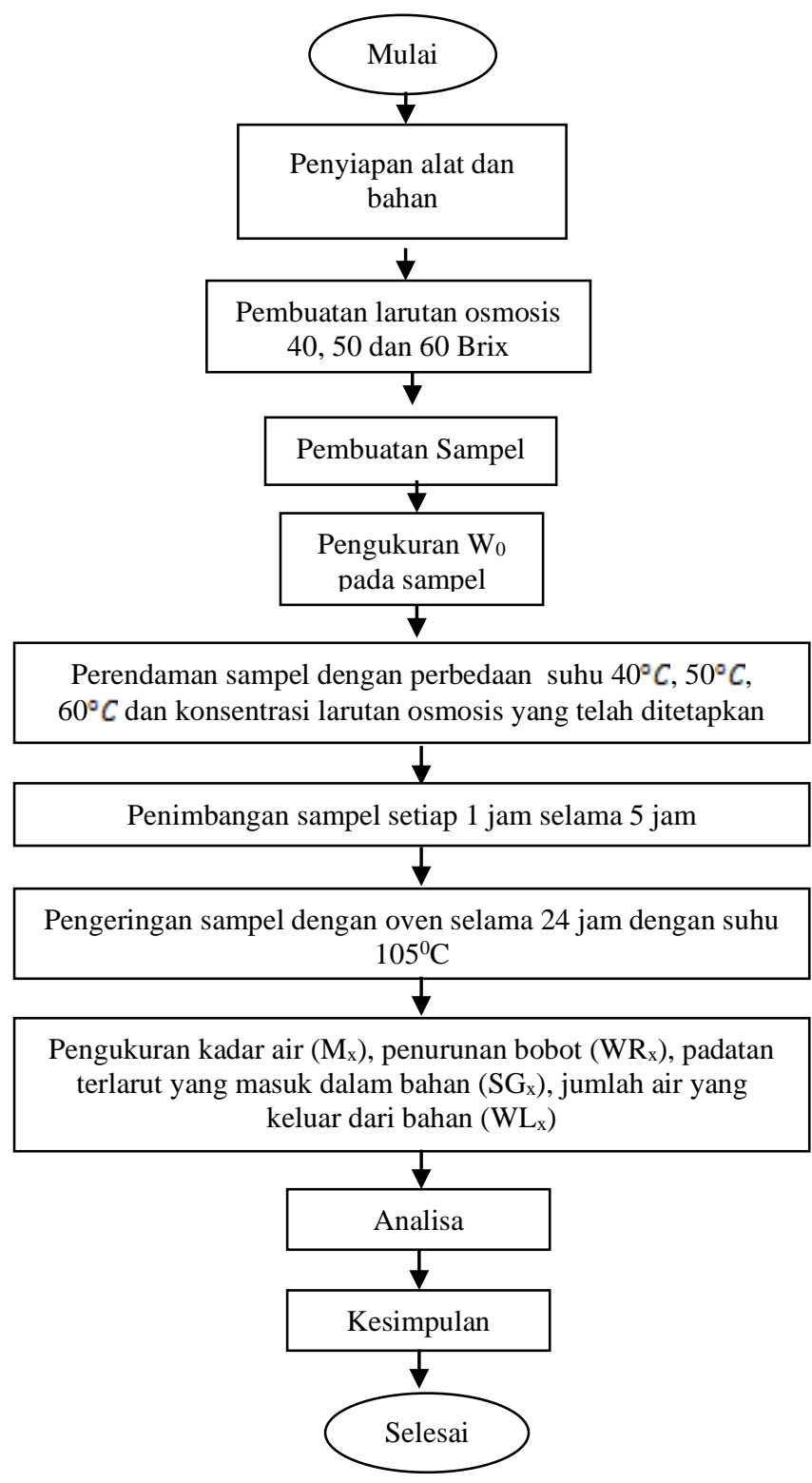

Gambar 1. Bagan Alir Penelitian

\section{HASIL DAN PEMBAHASAN}

\section{Perubahan Kadar Air}

Hasil Penelitian untuk Perubahan Kadar Air Akhir

Kadar air merupakan banyaknya air yang terkandung dalam bahan yang dinyatakan dalam persen. Adapun tabel hasil perubahan kadar air yang didapatkan dari hasil pengolahan data awal seperti pada tabel di bawah:
Jurnal AgriTechno. Vol. 12 (2): 110-120

https://doi.org/10.20956/at.v0i0.219

Tabel 1. Hasil penelitian untuk pengamatan kadar air akhir jam kelima.

\begin{tabular}{ccccc}
\hline \multirow{2}{*}{$\begin{array}{c}\text { Suhu } \\
\text { Perendaman } \\
\left({ }^{\circ} \mathrm{C}\right)\end{array}$} & \multicolumn{2}{c}{ Konsentrasi Larutan (Brix) } & \multirow{2}{*}{ Rata- } \\
\cline { 2 - 4 } & $40^{\circ}$ Brix & $\begin{array}{c}50^{\circ} \\
\text { Brix }\end{array}$ & $\begin{array}{c}60^{\circ} \\
\text { Brix }\end{array}$ & Rata \\
\hline $40^{\circ} \mathrm{C}$ & 73.46 & 69.97 & 65.78 & 69.74 \\
$50^{\circ} \mathrm{C}$ & 75.62 & 70.33 & 72.77 & 72.91 \\
$60^{\circ} \mathrm{C}$ & 61.41 & 59.72 & 58.13 & 59.76 \\
\hline Dari & Tabel 1 & hasil & penelitian & ini
\end{tabular}
menunjukkan bahwa kadar air akhir yang paling rendah berada pada kombinasi perlakuan suhu perendaman $60^{\circ} \mathrm{C}$ dan konsentrasi larutan $60^{\circ}$ Brix. Sedangkan nilai yang paling tinggi yakni kombinasi antara perendaman $50^{\circ} \mathrm{C}$ dan konsentrasi $40^{\circ}$ Brix.

Hubungan Kadar Air dengan
Waktu

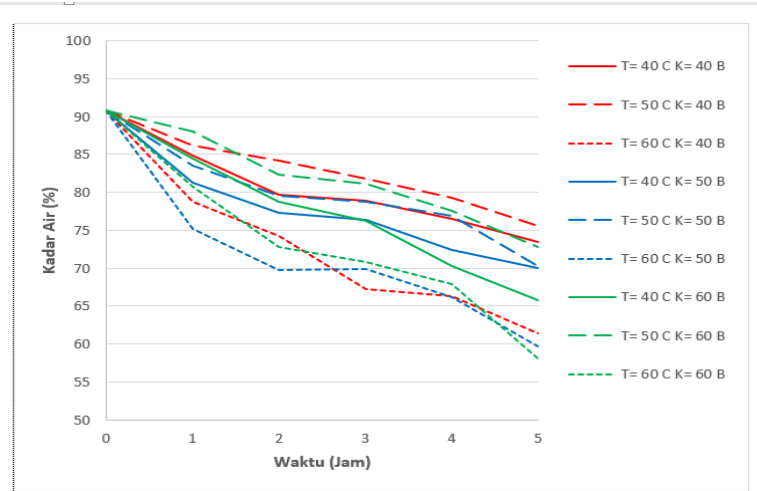

Gambar 2. Pengaruh Suhu Perendaman dan Konsentrasi Larutan Gula Terhadap Kadar Air Basis Basah Jam Kelima.

Grafik ini menunjukkan perlakuan suhu perendaman $60^{\circ} \mathrm{C}$ dan konsentrasi larutan gula $60^{\circ}$ Brix menghasilkan nilai kadar air yang paling rendah yakni sebesar $58.13 \%$.

Adapun Hubungan Interaksi antara Suhu dengan Konsentrasi Larutan Gula terhadap Kadar Air, sebagai berikut:

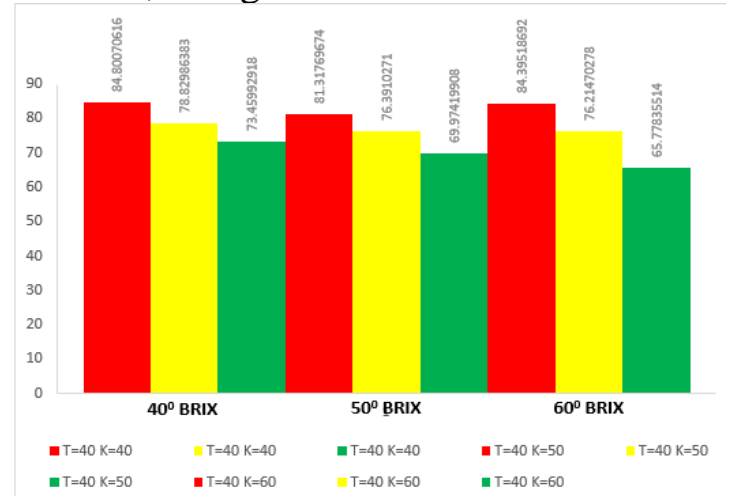

Gambar 3. Hubungan Interaksi Antara Suhu $\left(40^{\circ} \mathrm{C}\right)$ dengan Konsentrasi Larutan $\left(40^{\circ} \mathrm{Brix}\right.$, 
$50^{\circ}$ Brix dan $60^{\circ}$ Brix) Terhadap Penurunan

Kadar Air Pada Jam Pertama, Ketiga dan Kelima.

Pada Gambar 3 menunjukkan bahwa penurunan kadar air yang paling banyak terdapat pada interaksi hubungan suhu $40^{\circ} \mathrm{C}$ dan konsentrasi larutan gula $60^{\circ} \mathrm{Brix}$ pada jam kelima dengan nilai $65.77 \%$. Hal ini terjadi karena proses penurunan kadar air dipengaruhi oleh suhu dan konsentrasi larutan. Semakin tinggi suhu perendaman maka semakin tinggi penurunan kadar airnya.

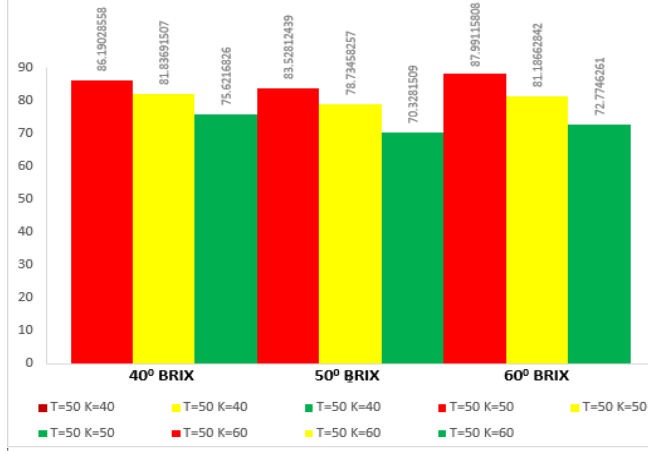

Gambar 4. Hubungan Interaksi Antara Suhu $\left(50^{\circ} \mathrm{C}\right)$ dengan Konsentrasi Larutan $\left(40^{\circ} \mathrm{Brix}\right.$, $50^{\circ}$ Brix dan $60^{\circ}$ Brix) Terhadap Penurunan

Kadar Air Pada Jam Pertama, Ketiga dan Kelima.

Pada Gambar 4 menunjukkan bahwa penurunan kadar air yang paling banyak terdapat pada interaksi hubungan suhu $50^{\circ} \mathrm{C}$ dan konsentrasi larutan gula $60^{\circ}$ Brix pada jam kelima dengan nilai $70.32 \%$. Hal ini terjadi karena proses penurunan kadar air dipengaruhi oleh suhu dan konsentrasi larutan. Semakin tinggi suhu perendaman maka semakin tinggi penurunan kadar airnya.

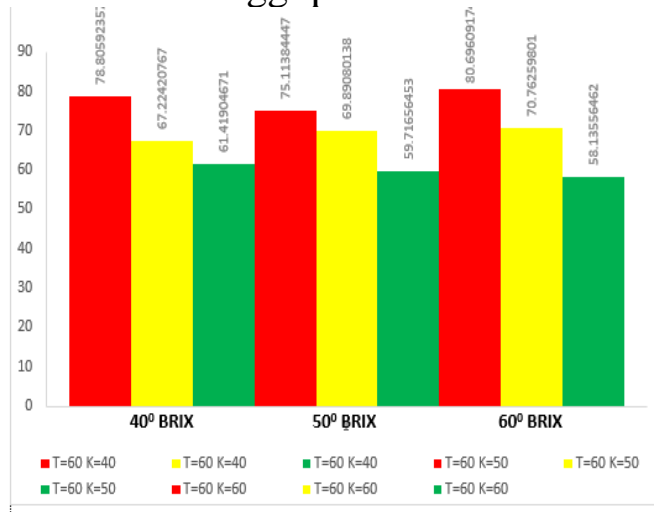

Gambar 5. Hubungan Interaksi Antara Suhu $\left(60^{\circ} \mathrm{C}\right)$ dengan Konsentrasi Larutan $\left(40^{\circ}\right.$ Brix, $50^{\circ}$ Brix dan $60^{\circ}$ Brix) Terhadap Penurunan Kadar Air Pada Jam Pertama, Ketiga dan Kelima.
Jurnal AgriTechno. Vol. 12 (2): 110-120

https://doi.org/ 10.20956/at.v0i0.219

Pada Gambar 5 menunjukkan bahwa penurunan kadar air yang paling banyak terdapat pada interaksi hubungan suhu $60^{\circ} \mathrm{C}$ dan konsentrasi larutan gula $60^{\circ} \mathrm{Brix}$ pada jam kelima dengan nilai $65.77 \%$. Hal ini terjadi karena proses penurunan kadar air dipengaruhi oleh suhu dan konsentrasi larutan. Semakin tinggi suhu perendaman maka semakin tinggi penurunan kadar airnya.

\section{Analisis Ragam untuk Kadar Air Akhir}

Berdasarkan uji analisis ragam, diketahui jika $F_{\text {hitung }}>F_{1 \%}$. Maka, Ha diterima atau perlakuan (suhu dan konsentrasi larutan) yang diberikan secara individu berpengaruh sangat nyata pada proses penurunan kadar air. Sampel tiap perlakuan memiliki kadar air awal yaitu dengan $90.79 \%$ basis basah. Kadar air bahan diukur sebelum, selama dan setelah dilakukan proses dehidrasi osmosis sehingga diperoleh nilai parameter pengukuran awal dan akhir. Dalam proses dehidrasi osmosis sampel akan mengalami penurunan kadar air selama prosesnya berlangsung, kadar air akhir sampel yaitu dengan kisaran rata-rata 50\% $75 \%$ basis basah. Menurunnya nilai kadar air disebabkan karena terjadinya perbedaan konsentrasi zat terlarut antara sampel dan larutan gula yang menyebabkan perbedaan tekanan osmosis antara air dalam jaringan sampel dengan larutan gula sehingga air dalam sampel akan keluar dari jaringan sampel ke larutan gula.

Selanjutnya, waktu yang dibutuhkan untuk menurunkan kadar air pada proses dehidrasi osmosis yang dilakukan yaitu selama 5 jam pada suhu $105^{\circ} \mathrm{C}$. Penurunan kadar air disebabkan karena adanya perbedaan tekanan osmosis sehingga air dalam permukaan sampel lebih cepat keluar ke larutan osmosis. Padatan terlarut yang terdapat pada larutan osmosis sebagian akan keluar dan masuk ke dalam sampel. Adapun interaksi antara perlakuan suhu dan konsentrasi larutan osmosis dapat sangat berpengaruh pada penurunan kadar air. Sesuai dengan pendapat Sohibulloh (2013), bahwa suhu dan konsentrasi larutan memberikan pengaruh pada proses dehidrasi osmosis. 
Weight Reduction (WR)

Hasil penelitian untuk perubahan Weight Reduction (WR).

Weight reduction merupakan penurunan bobot bahan dalam proses pengurangan kadar air bahan yang dinyatakan dalam persen. Adapun tabel hasil untuk WR, seperti pada tabel di bawah:

Tabel 2. Hasil penelitian untuk pengukuran Weight Reduction (WR) jam kelima.

\begin{tabular}{ccccc}
\hline \multirow{2}{*}{$\begin{array}{c}\text { Suhu } \\
\text { Perendaman }\end{array}$} & \multicolumn{2}{c}{ Konsentrasi Larutan $($ Brix $)$} & $\begin{array}{c}\text { Rata- } \\
\text { Rata }\end{array}$ \\
\cline { 2 - 4 } & $40^{\circ}$ Brix & $50^{\circ}$ Brix & $60^{\circ}$ Brix & \\
\hline $40^{\circ} \mathrm{C}$ & 16.43 & 26.42 & 33.29 & 25.38 \\
$50^{\circ} \mathrm{C}$ & 29.81 & 41.03 & 33.62 & 35.82 \\
$60^{\circ} \mathrm{C}$ & 30.63 & 33.16 & 32.72 & 32.17 \\
\hline
\end{tabular}

Dari Tabel 2 hasil penelitian untuk perubahan nilai Weight Reduction (WR) akhir menunjukkan bahwa nilai akhir yang paling tinggi berada pada kombinasi perlakuan suhu perendaman $50^{\circ} \mathrm{C}$ dan konsentrasi larutan $50^{\circ}$ Brix. Hal ini terjadi karena suhu perendaman dan konsentasi larutan mempengaruhi penurunan bobot. Hal ini sesuai dengan pendapat Magdalena (2014), bahwa peningkatan konsentrasi larutan osmosi menghasilkan peningkatan kehilangan air pada bahan terhadap tingkat pengeringan yang menyebabkan peningkatan penurunan bobot.

\section{Hubungan Weight Reduction (WR) dengan Waktu.}

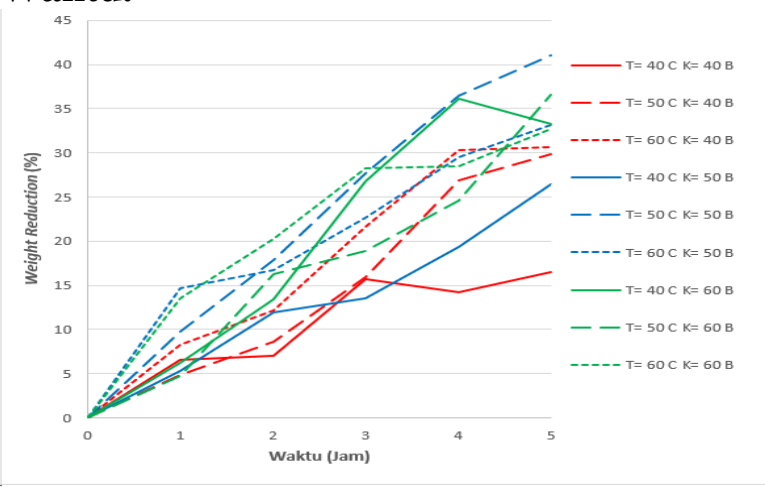

Gambar 6. Pengaruh Suhu Perendaman dan Konsentrasi Larutan Gula Terhadap Weight Reduction (WR) Jam Kelima.

Gambar 6 merupakan grafik pengaruh suhu perendaman $\left(40^{\circ} \mathrm{C}, 50^{\circ} \mathrm{C}\right.$ dan $\left.60^{\circ} \mathrm{C}\right)$ dan konsentrasi larutan gula $\left(40^{\circ} \mathrm{Brix}, 50^{\circ} \mathrm{Brix}\right.$ dan $60^{\circ}$ Brix) terhadap Weight Reduction (WR). Pada grafik ini menunjukkan perlakuan suhu perendaman $50^{\circ} \mathrm{C}$ dan konsentrasi larutan gula $50^{\circ}$ Brix menghasilkan nilai Weight Reduction (WR) yang paling tinggi yaitu dengan nilai sebesar $41.03 \%$. Hal tersebut sesuai dengan penelitian yang dilakukan oleh Magdalena (2014), bahwa jika suhu larutan osmosis dapat berpengaruh dalam perubahan struktur dinding sel dan juga kerapatan, maka bisa mempengaruhi transfer massa ataupun permeasi. Jika semakin tinggi suhu perendaman, maka struktur dinding sel dan kerapatannya akan semakin berkurang, sehingga mempercepat transfer massa dan permeasi pada proses osmosis.

Adapun Hubungan Interaksi antara Suhu dengan Konsentrasi Larutan Gula terhadap Weight Reduction (WR), sebagai berikut:

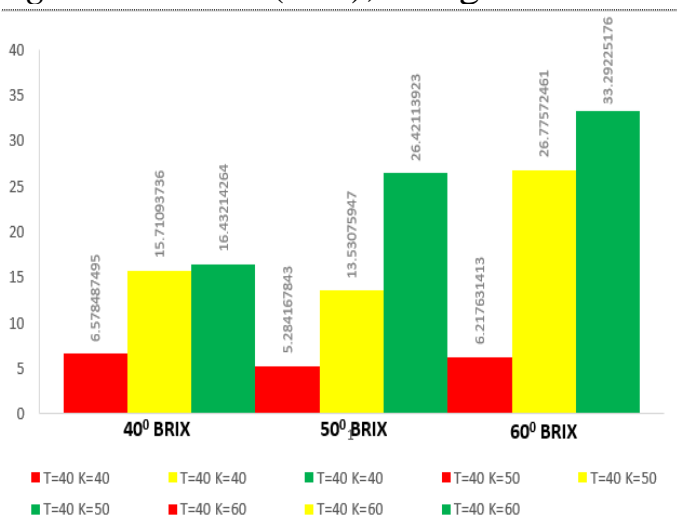

Gambar 7. Hubungan Interaksi Antara Suhu $\left(40^{\circ} \mathrm{C}\right)$ dengan Konsentrasi Larutan $\left(40^{\circ} \mathrm{Brix}\right.$, $50^{\circ}$ Brix dan $60^{\circ}$ Brix) Terhadap Penurunan

Kadar Air Pada Jam Pertama, Ketiga dan Kelima.

Pada Gambar 7 menunjukkan bahwa hubungan interaksi suhu dan konsentrasi larutan gula terhadap Weight Reduction (WR). Nilai perubahan Weight Reduction (WR) yang paling tinggi ditunjukkan pada interaksi hubungan suhu $40^{\circ} \mathrm{C}$ dan konsentrasi larutan gula $60^{\circ}$ Brix dengan nilai $29.22 \%$. Hal ini terjadi karena nilai Weight Reduction (WR) dipengaruhi oleh suhu dan konsentrasi larutan gula. Suhu menjadi variabel penting dalam proses penurunan kadar air suatu bahan atau produk yang akan digunakan (Magdalena, 2014). 


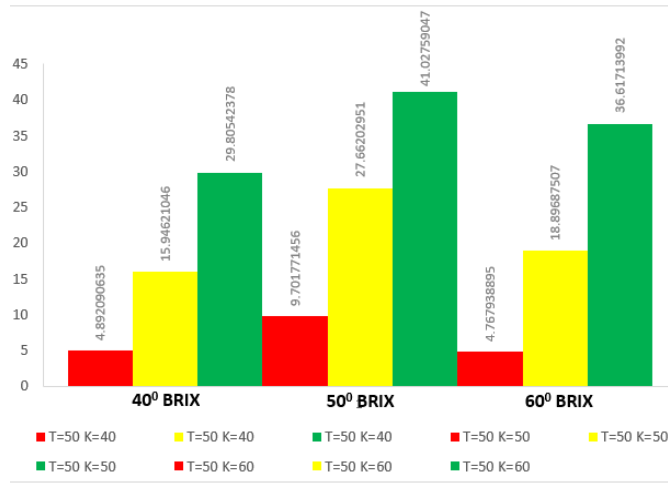

Gambar 8. Hubungan Interaksi Antara Suhu $\left(50^{\circ} \mathrm{C}\right)$ dengan Konsentrasi Larutan $\left(40^{\circ} \mathrm{Brix}\right.$, $50^{\circ}$ Brix dan $60^{\circ}$ Brix) Terhadap Penurunan Kadar Air Pada Jam Pertama, Ketiga dan Kelima.

Pada Gambar 8 menunjukkan bahwa hubungan interaksi suhu dan konsentrasi larutan gula terhadap Weight Reduction (WR). Nilai perubahan Weight Reduction (WR) yang paling tinggi ditunjukkan pada interaksi hubungan suhu $50^{\circ} \mathrm{C}$ dan konsentrasi larutan gula $50^{\circ}$ Brix dengan nilai $41.02 \%$. Hal ini terjadi karena nilai Weight Reduction (WR) dipengaruhi oleh suhu dan konsentrasi larutan gula. Suhu menjadi variabel penting dalam proses penurunan kadar air suatu bahan atau produk yang akan digunakan (Magdalena, 2014).

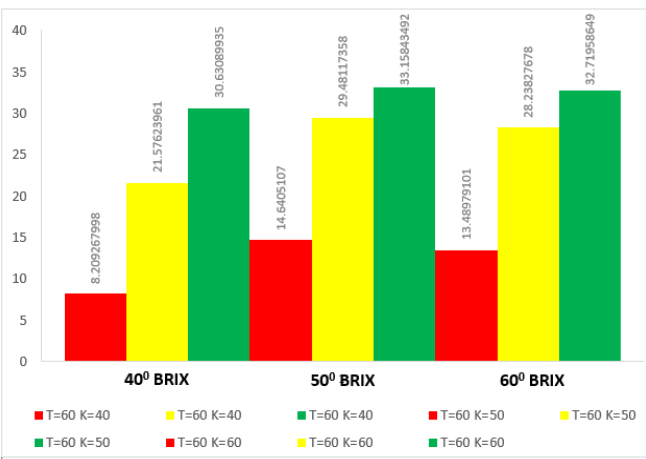

Gambar 9. Hubungan Interaksi Antara Suhu $\left(60^{\circ} \mathrm{C}\right)$ dengan Konsentrasi Larutan $\left(40^{\circ} \mathrm{Brix}\right.$, $50^{\circ}$ Brix dan $60^{\circ}$ Brix) Terhadap Penurunan Kadar Air Pada Jam Pertama, Ketiga dan Kelima.

Pada Gambar 9 menunjukkan bahwa hubungan interaksi suhu dan konsentrasi larutan gula terhadap Weight Reduction (WR). Nilai perubahan Weight Reduction (WR) yang paling tinggi ditunjukkan pada interaksi hubungan suhu $60^{\circ} \mathrm{C}$ dan konsentrasi larutan gula $50^{\circ}$ Brix dengan nilai $33.15 \%$. Hal ini terjadi karena nilai Weight Reduction
(WR) dipengaruhi oleh suhu dan konsentrasi larutan gula. Suhu menjadi variabel penting dalam proses penurunan kadar air suatu bahan atau produk yang akan digunakan (Magdalena, 2014).

Water Loss (WL)

Hasil penelitian untuk perubahan Water Loss (WL)

Water loss (WL) merupakan jumlah air yang hilang selama proses dehidrasi osmosis terjadi nilainya dinyatakan dalam persen. Adapun Tabel hasil untuk Water loss (WL), seperti pada tabel di bawah:

Tabel 3. Hasil penelitian untuk pengukuran Water Loss (WL)

Dari Tabel 3 hasil penelitian untuk

\begin{tabular}{ccccc}
\hline \multirow{2}{*}{$\begin{array}{c}\text { Suhu } \\
\text { Perendaman } \\
\left({ }^{\circ} \mathrm{C}\right)\end{array}$} & \multicolumn{3}{c}{ Konsentrasi Larutan (Brix) } & Rata- \\
\cline { 2 - 4 } & $\begin{array}{c}40^{\circ} \\
\text { Brix }\end{array}$ & $\begin{array}{c}50^{\circ} \\
\text { Brix }\end{array}$ & $\begin{array}{c}60^{\circ} \\
\text { Brix }\end{array}$ & Rata \\
\hline $40^{\circ} \mathrm{C}$ & 17.88 & 28.09 & 35.11 & 27.03 \\
$50^{\circ} \mathrm{C}$ & 31.03 & 42.37 & 37.73 & 37.04 \\
$60^{\circ} \mathrm{C}$ & 32.95 & 35.77 & 35.54 & 34.75 \\
\hline rubahan & Water & Loss & $(\mathrm{WL})$ & akhir
\end{tabular}

perubahan Water Loss (WL) akhir, menunjukkan bahwa hasil yang paling rendah berada pada kombinasi perlakuan suhu perendaman $40^{\circ} \mathrm{C}$ dan konsentrasi larutan gula $40^{\circ}$ Brix, dan nilai Water Loss (WL) yang paling tinggi berada pada kombinasi perlakuan suhu perendaman $50^{\circ} \mathrm{C}$ dan konsentrasi larutan $50^{\circ}$ Brix. Hasil tersebut sesuai dengan pernyataan Wirawan (2013), bahwa suhu dan konsentrasi larutan memberikan pengaruh pada proses dehidrasi osmosis, karena suhu perendaman dapat berpengaruh terhadap dinding sel dan kerapatan antara sel yang satu dengan lainnya.

\section{Hubungan Water Loss (WL) dengan} Waktu.

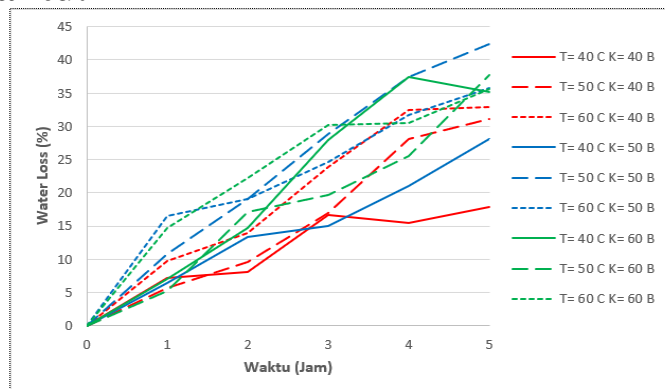

Gambar 10. Pengaruh Suhu Perendaman dan Konsentrasi Larutan Gula Terhadap Weight Reduction (WR) Jam Kelima. 
Gambar 10 merupakan grafik hubungan pengaruh suhu perendaman $\left(40^{\circ} \mathrm{C}, 50^{\circ} \mathrm{C}\right.$ dan $\left.60^{\circ} \mathrm{C}\right)$ dan konsentrasi larutan gula $\left(40^{\circ} \mathrm{Brix}\right.$, $50^{\circ}$ Brix dan $60^{\circ}$ Brix) terhadap Water Loss (WL). Pada grafik ini menunjukkan perlakuan suhu perendaman $50^{\circ} \mathrm{C}$ dan konsentrasi larutan gula $50^{\circ}$ Brix menghasilkan nilai Water Loss (WL) yang paling tinggi yaitu dengan nilai sebesar $42.37 \%$. Hal ini sesuai dengan pendapat Magdalena et al. (2014), meningkatnya perubahan nilai Water Loss (WL) disebabkan karena adanya perbedaan tekanan osmosis yang lebih besar antara larutan gula dengan air dalam bahan. Perbedaan tekanan tersebut menjadi driving force yang menyebabkan massa air pada bahan mengalir keluar dari bahan menuju media larutan. Hal tersebut juga diketahui jika semakin besar bertambahnya konsentrasi larutan osmosis yang diberikan, maka semakin besar pula perubahan nilai Water Loss (WL) yang terjadi. Seperti penelitian yang telah dilakukan oleh Wirawan dan Anasta (2013), bahwa konsentrasi larutan memberikan pengaruh beda potensial dalam sistem dehidrasi osmosis. Jika beda potensialnya semakin tinggi, maka semakin cepat pula air yang akan keluar dari dalam bahan makanan.

Adapun Hubungan Interaksi antara Suhu dengan Konsentrasi Larutan Gula terhadap Water Loss (WL), sebagai berikut:

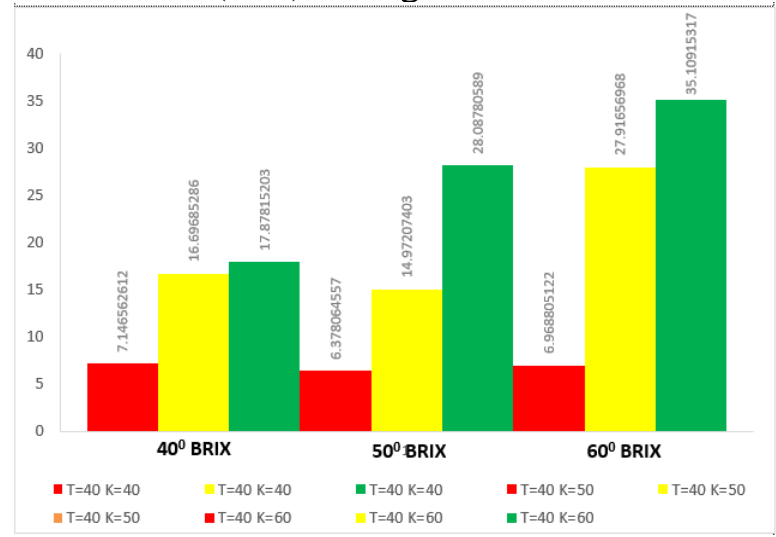

Gambar 11. Hubungan Interaksi Antara Suhu $\left(40^{\circ} \mathrm{C}\right)$ dengan Konsentrasi Larutan $\left(40^{\circ} \mathrm{Brix}\right.$, $50^{\circ}$ Brix dan $60^{\circ}$ Brix) Terhadap Penurunan

Kadar Air Pada Jam Pertama, Ketiga dan Kelima.

Nilai Water Loss (WL) yang paling tinggi ditunjukkan pada interaksi hubungan suhu $40^{\circ} \mathrm{C}$ dan konsentrasi larutan gula $60^{\circ} \mathrm{Brix}$ dengan nilai $35.10 \%$. Hal ini terjadi karena nilai Water Loss (WL) dipengaruhi oleh suhu perendaman dan konsentrasi larutan. Hal ini sesuai dengan pendapat Wirawan (2013), bahwa suhu dapat menjadi variabel penting dalam proses perubahan nilai Water Loss (WL) suatu bahan atau produk yang akan digunakan.

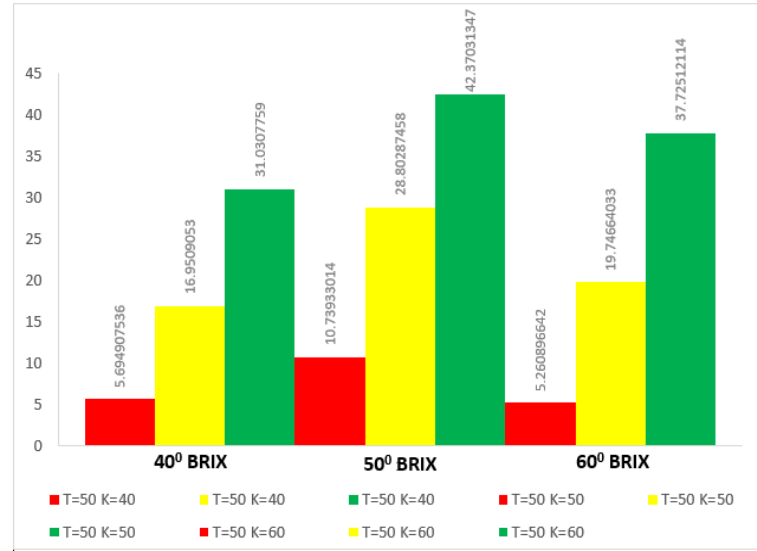

Gambar 12. Hubungan Interaksi Antara Suhu $\left(50^{\circ} \mathrm{C}\right)$ dengan Konsentrasi Larutan $\left(40^{\circ} \mathrm{Brix}\right.$, $50^{\circ}$ Brix dan $60^{\circ}$ Brix) Terhadap Penurunan Kadar Air Pada Jam Pertama, Ketiga dan Kelima.

Nilai Water Loss (WL) yang paling tinggi ditunjukkan pada interaksi hubungan suhu $50^{\circ} \mathrm{C}$ dan konsentrasi larutan gula $50^{\circ}$ Brix dengan nilai $42.37 \%$. Hal ini terjadi karena nilai Water Loss (WL) dipengaruhi oleh suhu perendaman dan konsentrasi larutan. Hal ini sesuai dengan pendapat Wirawan (2013), bahwa suhu dapat menjadi variabel penting dalam proses perubahan nilai Water Loss (WL) suatu bahan atau produk yang akan digunakan.

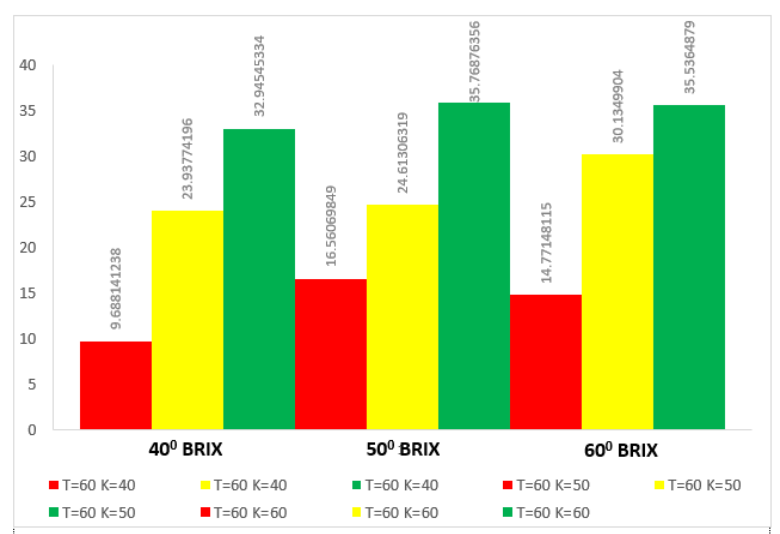

Gambar 13. Hubungan Interaksi Antara Suhu $\left(60^{\circ} \mathrm{C}\right)$ dengan Konsentrasi Larutan $\left(40^{\circ} \mathrm{Brix}\right.$, $50^{\circ}$ Brix dan $60^{\circ}$ Brix) Terhadap Penurunan 
Kadar Air Pada Jam Pertama, Ketiga dan Kelima.

Nilai Water Loss (WL) yang paling tinggi ditunjukkan pada interaksi hubungan suhu $60^{\circ} \mathrm{C}$ dan konsentrasi larutan gula $50^{\circ}$ Brix dengan nilai $35.76 \%$. Hal ini terjadi karena nilai Water Loss (WL) dipengaruhi oleh suhu perendaman dan konsentrasi larutan. Hal ini sesuai dengan pendapat Wirawan (2013), bahwa suhu dapat menjadi variabel penting dalam proses perubahan nilai Water Loss (WL) suatu bahan atau produk yang akan digunakan.

\section{Solid Gain (SG)}

\section{Hasil Penelitian untuk Solid Gain (SG)}

Solid Gain (SG) merupakan banyaknya padatan yang masuk ke dalam bahan pada proses dehidrasi osmosis yang dinyatakan dalam persen. Adapun Tabel hasil untuk SG, seperti pada tabel di bawah:

Tabel 4. Hasil penelitian untuk pengukuran Solid Gain (SG) Jam Kelima.

\begin{tabular}{ccccc}
\hline \multirow{2}{*}{$\begin{array}{c}\text { Suhu } \\
\text { Perendaman } \\
\left({ }^{\circ} \mathrm{C}\right)\end{array}$} & \multicolumn{2}{c}{ Konsentrasi Larutan (Brix) } & $\begin{array}{c}\text { Rata- } \\
\text { Rata }\end{array}$ \\
\cline { 2 - 4 } $40^{\circ}$ Brix & $50^{\circ}$ Brix & $60^{\circ}$ Brix & \\
\hline $40^{\circ} \mathrm{C}$ & 1.45 & 1.67 & 1.82 & 1.65 \\
$50^{\circ} \mathrm{C}$ & 1.23 & 1.34 & 1.11 & 1.23 \\
$60^{\circ} \mathrm{C}$ & 2.31 & 2.61 & 2.82 & 2.58 \\
\hline
\end{tabular}

Dari Tabel 4 hasil penelitian untuk perubahan nilai Solid Gain (SG) akhir menunjukkan bahwa hasil yang paling rendah berada pada kombinasi perlakuan suhu perendaman $50^{\circ} \mathrm{C}$ dan konsentrasi larutan $60^{\circ}$ Brix, sedangkan pada kombinasi perlakuan suhu perendaman $60^{\circ} \mathrm{C}$ dan konsentrasi larutan $60^{\circ}$ Brix diperoleh nilai yang paling tinggi. Hasil penelitian tersebut sesuai dengan pendapat Wirawan (2013), bahwa suhu dan konsentrasi larutan memberikan pengaruh pada proses dehidrasi osmosis. Suhu perendaman berpengaruh terhadap dinding sel dan kerapatan antara sel yang satu dengan lainnya. Sedangkan, konsentrasi larutan gula berpengaruh terhadap beda potensial antara dua jenis larutan yang berbeda konsentrasinya.

\section{Hubungan Solid Gain (SG) dengan Waktu}

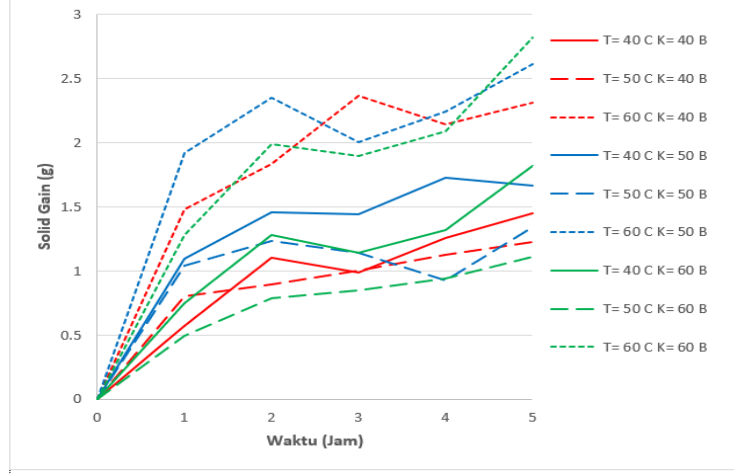

Gambar 14. Pengaruh Suhu Perendaman dan

Konsentrasi Larutan Gula Terhadap Solid Gain (SG) Jam Kelima.

Pada grafik di atas menunjukkan perlakuan suhu perendaman $60^{\circ} \mathrm{C}$ dan konsentrasi larutan gula $60^{\circ} \mathrm{Brix}$ menghasilkan nilai Solid Gain (SG) yang paling tinggi yaitu sebesar $2.82 \mathrm{~g}$. Hal ini sesuai dengan pendapat Magdalena et al. (2014), meningkatnya nilai Solid Gain (SG) disebabkan karena adanya perbedaan tekanan osmosis yang lebih besar antara larutan gula dengan air dalam bahan. Perbedaan tekanan tersebut dapat menyebabkan massa air pada bahan mengalir keluar dari bahan menuju media larutan. Seperti penelitian sebelumnya yang dilakukan oleh Wirawan dan Anasta (2013), bahwa konsentrasi larutan memberikan pengaruh beda potensial dalam sistem dehidrasi osmosis.

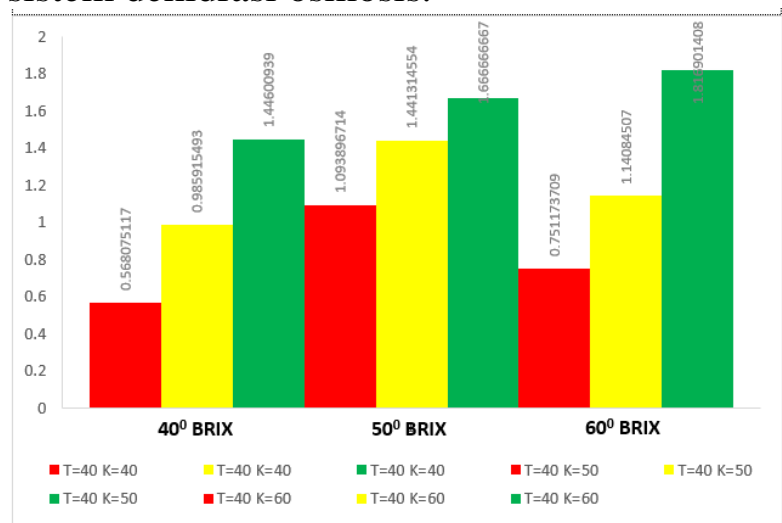

Gambar 15. Hubungan Interaksi Antara Suhu $\left(40^{\circ} \mathrm{C}\right)$ dengan Konsentrasi Larutan $\left(40^{\circ} \mathrm{Brix}\right.$, $50^{\circ}$ Brix dan $60^{\circ}$ Brix) Terhadap Penurunan Solid Gain (SG) Pada Jam Pertama, Ketiga dan Kelima.

Padatan yang masuk ke dalam bahan paling banyak ada pada kombinasi antara suhu $40^{\circ} \mathrm{C}$ dan konsentrasi $60^{\circ}$ Brix dengan nilai 1.81 g. Hal tersebut terjadi karena Solid 
Gain (SG) dipengaruhi oleh peningkatan suhu. Semakin tinggi suhu maka akan semakin tinggi pula padatan yang masuk ke dalam bahan. Hal ini sesuai dengan pernyataan Chavan (2012), kehilangan air dan gula peningkatannya linier dengan peningkatan suhu dan konsentrasi gula. Konsentrasi gula dan suhu berfungsi dalam proses peningkatan defuse gula.

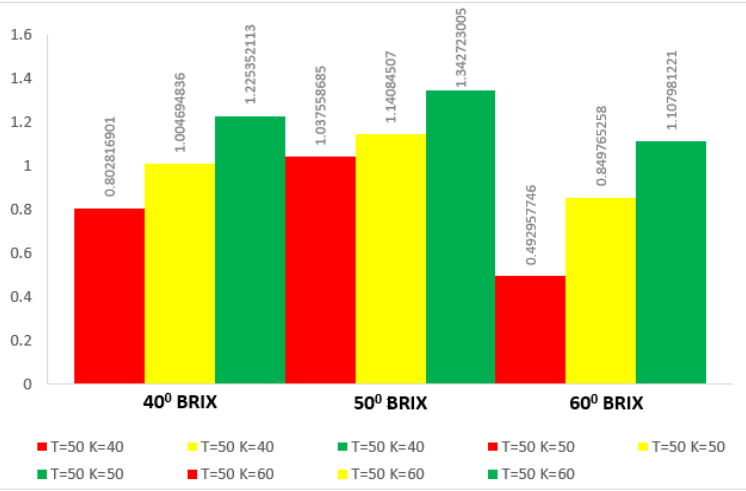

Gambar 16. Hubungan Interaksi Antara Suhu $\left(50^{\circ} \mathrm{C}\right)$ dengan Konsentrasi Larutan $\left(40^{\circ} \mathrm{Brix}\right.$, $50^{\circ}$ Brix dan $60^{\circ}$ Brix) Terhadap Penurunan Solid Gain (SG) Pada Jam Pertama, Ketiga dan Kelima.

Padatan yang masuk ke dalam bahan paling banyak ada pada kombinasi antara suhu $50^{\circ} \mathrm{C}$ dan konsentrasi $50^{\circ}$ Brix dengan nilai $1.34 \mathrm{~g}$. Hal tersebut terjadi karena Solid Gain (SG) dipengaruhi oleh peningkatan suhu. Semakin tinggi suhu maka akan semakin tinggi pula padatan yang masuk ke dalam bahan. Hal ini sesuai dengan pernyataan Chavan (2012), kehilangan air dan gula peningkatannya linier dengan peningkatan suhu dan konsentrasi gula. Konsentrasi gula dan suhu berfungsi dalam proses peningkatan defuse gula.

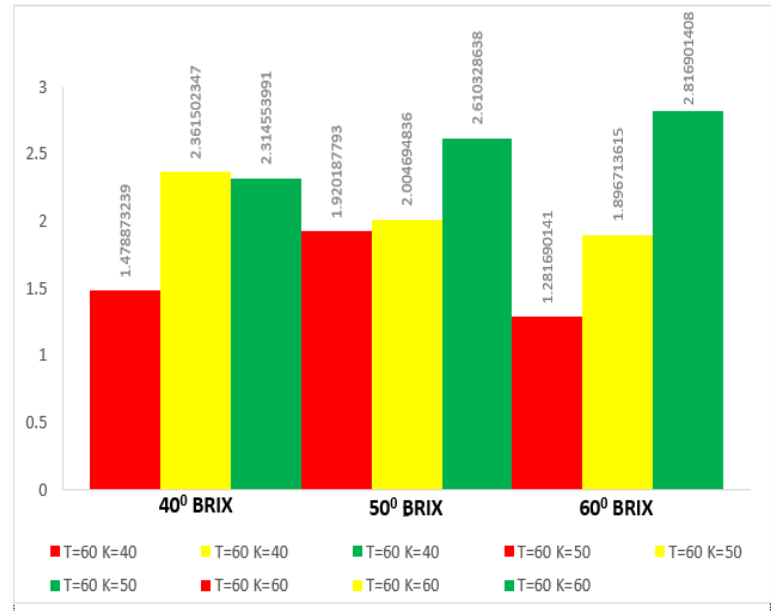

Gambar 17. Hubungan Interaksi Antara Suhu $\left(50^{\circ} \mathrm{C}\right)$ dengan Konsentrasi Larutan $\left(40^{\circ} \mathrm{Brix}\right.$, $50^{\circ}$ Brix dan $60^{\circ}$ Brix) Terhadap Penurunan Solid Gain (SG) Pada Jam Pertama, Ketiga dan Kelima.

Padatan yang masuk ke dalam bahan paling banyak ada pada kombinasi antara suhu $60^{\circ} \mathrm{C}$ dan konsentrasi $60^{\circ}$ Brix dengan nilai 2.31 g. Hal tersebut terjadi karena Solid Gain (SG) dipengaruhi oleh peningkatan suhu. Semakin tinggi suhu maka akan semakin tinggi pula padatan yang masuk ke dalam bahan. Hal ini sesuai dengan pernyataan Chavan (2012), kehilangan air dan gula peningkatannya linier dengan peningkatan suhu dan konsentrasi gula. Konsentrasi gula dan suhu berfungsi dalam proses peningkatan defuse gula.

\section{KESIMPULAN}

Adapun kesimpulan pada penelitian ini yakni,

1. Perlakuan suhu perendaman $60^{\circ} \mathrm{C}$ dan konsentrasi larutan gula $60^{\circ}$ Brix menghasilkan nilai akhir kadar air yang paling rendah.

2. Perlakuan suhu perendaman $50^{\circ} \mathrm{C}$ dan konsentrasi larutan gula $50^{\circ} \mathrm{Brix}$ menghasilkan nilai Weight Reduction (WR) yang paling tinggi.

3. Pada perlakuan suhu perendaman $50^{\circ} \mathrm{C}$ dan konsentrasi larutan gula $50^{\circ}$ Brix menghasilkan nilai Water Loss (WL) yang paling tinggi.

4. Pada perlakuan suhu perendaman $60^{\circ} \mathrm{C}$ dan konsentrasi larutan gula $60^{\circ}$ Brix menghasilkan nilai akhir Solid Gain (SG) yang paling tinggi.

5. Suhu dan konsentrasi larutan gula yang efektif digunakan dalam proses dehidrasi osmosis ini adalah suhu perendaman dan konsentrasi larutan gula yang paling tinggi, yaitu suhu $60^{\circ} \mathrm{C}$ dan konsentrasi $60^{\circ} \mathrm{Brix}$.

\section{DAFTAR PUSTAKA}

Chavan, U.D. and Amarowicz R. 2012. Osmotic Dehydration Process for Preservation of Fruits and 
Vegetables. Canadian Center of Science and Education: Kanada.

Herdiyantoro, D. 2013. Rancangan Faktorial Rancangan Acak Lengkap dan Rancangan Acak Kelompok. Universitas Padjadjaran: Bandung.

Kartika, P.N. 2015. Studi Pembuatan Osmodehidrat Buah Nanas (Ananas Comosus L. Merr): Kajian Konsentrasi Gula Dalam Larutan Osmosis Dan Lama Perendaman. Universitas Brawijaya: Malang.

Magdalena, A.S.W. 2014. Pengaruh Suhu dan Konsentrasi Larutan Gula Terhadap Proses Dehidrasi Osmosis Buah Waluh (Cucurbita Moschata). Universitas Lampung: Lampung.

Sanket, C.K. 2006. Modelling the drying behaviour of salted catfish fillets. 15th International Drying Symposium. Budapest, Hungary.

Sharma, S.K. 2000. Food Process Engineering: Theory and Laboratory Experiments. WileyInterscience: New York.

Wirawan, S.K. 2013. Analisis Permeasi Air Pada Dehidrasi Osmosis Pepaya (Carica papaya L.). Universitas Gadjah Mada: Yogyakarta.

Witono, B., Y.I.P. 2013. Studi Kinetika Dehidrasi Osmosis Pada Ikan Teri Dalam Larutan Biner Dan Terner. Universitas Katolik Parahyangan: Parahyangan. 